\title{
PRECIPITATION REACTION OF CLAVULANIC ACID: THERMODYNAMIC AND ELECTRONIC STUDY
}

\author{
Ana C. Granato ${ }^{\mathrm{a}, \#, * \text { Edson B. Costa }}$, Wagner F. D. Angelottic ${ }^{\mathrm{c}}$, Geoffroy R. P. Malpass ${ }^{\mathrm{a}, \# \text {, Marlei Barboza }}$,, Albérico B. \\ F. da Silva ${ }^{d}$ and Milan Trsic ${ }^{d}$
}

aDepartamento de Engenharia Química, Universidade Federal do Triângulo Mineiro, 38025-180 Uberaba - MG, Brasil

bEscola de Aplicação da Universidade Federal do Pará, 66095-780 Belém - PA, Brasil

cDepartamento de Matemática Aplicada, Universidade Federal do Triângulo Mineiro, 38025-180 Uberaba - MG, Brasil

'Instituto de Química de São Carlos, 13560-970 São Carlos - SP, Brasil

Recebido em 15/01/2016; aceito em 31/03/2016; publicado na web em 06/06/2016

\begin{abstract}
In the present article the theoretical calculation of thermodynamic parameters for the two main precipitation agents, potassium 2-ethylhexanoate and t-octylamine, employed by the pharmaceutical industry to obtain potassium clavulanate for clinical use, is described. The results obtained using the standard thermochemistry calculation in the Gaussian package and by calculation of the reactivity indexes of the reagents and products are compared. The calculated thermodynamic parameters indicate that the reactivity indexes present a better correlation with the experimentally obtained percentage yield. In addition, a series of additional precipitation agents that are also used in industrial procedures to obtain potassium clavulanate for clinical use, were compared. This was done to verify if any present, a priori, better properties than potassium 2-ethylhexanoate or t-octylamine. The consistency of the reactivity indexes calculated clearly suggests that the methodology employed can be used to screen future precipitation agents for possible use in the production of potassium clavulanate.
\end{abstract}

Keywords: clavulanic acid; potassium 2-ethylhexanoate; t-octylamine; molecular orbital; precipitation.

\section{INTRODUCTION}

Clavulanic acid (CA) is a $\beta$-lactam compound, which consists of a $\beta$-lactam ring condensed to an oxazolidin ring; it is a secondary metabolite isolated from Streptomyces clavuligerus, which inhibits most class A $\beta$-lactamases, has low activity against class $\mathrm{C}$ cephalosporinases and is inactive against class $\mathrm{B} \mathrm{Zn}^{2+}$ methaloenzymes. Combinations of CA with a broad-spectrum antibiotic are in clinical use to combat a wide range of infections. ${ }^{1-4}$

Amongst the possible purification methodologies, the precipitation reaction is one of the best options to obtain CA. One procedure is to react $\mathrm{CA}$ with potassium 2-ethylhexanoate in the solvent-rich phase (i.e. after cell removal) and the resulting clarified broth is acidified to $\mathrm{pH}$ values between 2 and 3 . CA is then extracted using organic solvents such as ethyl acetate and the salt is formed. ${ }^{5,6}$ Another process involves a process in which a stable CA intermediate is formed that is subsequently converted to potassium clavulanate using potassium 2-ethylhexanoate. ${ }^{7-14}$

Hirata et al..$^{14,15}$ carried out both precipitation reactions referred to above, i.e., the direct reaction between CA and potassium 2-ethylhexanoate and the indirect reaction between $\mathrm{CA}$ and t-octylamine. Both reactions were performed using the cultivation broth to produce $\mathrm{CA}$, using ethyl acetate as the solvent. The authors report that the reaction to produce the intermediate using t-octylamine presents higher selectivity when compared to the direct reaction between CA and potassium 2-ethylhexanoate. The authors explain that this is because the direct reaction also precipitates large amounts of impurities together with potassium clavulanate. It was also observed that the reaction with t-octylamine, in addition to releasing potassium clavulanate with high purity, also led to a higher percentage yield and high quality crystals. These results indicated that the reaction with the intermediate formation is the best for reproduction on an industrial scale.

*e-mail: acgmalpass.uftm@gmail.com

\#Mestrado Profissional em Inovação Tecnológica - PMPIT-UFTM
Based on the results reported by Hirata et al..$^{14,15}$ this study aims to calculate the theoretical thermodynamic and electronic properties involved in both reactions to verify if these parameters correlate with the experimental data reported. Thus it is possible to define, from a thermodynamic point of view, which of the two options is most attractive. In addition, the results of the electronic studies open up research possibilities for other reagents, with the aim of understanding their impact on the efficiency of the process.

\section{EXPERIMENTAL}

In order to calculate the thermodynamic parameters - standard molar enthalpy variation $\left(\Delta \mathrm{H}^{\circ}, \mathrm{kcal} / \mathrm{mol}\right)$ and standard molar Gibbs energy variation $\left(\Delta \mathrm{G}^{\circ}, \mathrm{kcal} / \mathrm{mol}\right)$, the Zero Point Energy approximation methodology (ZPE) described by Ochterski ${ }^{16}$ was used. In a previous study by the present authors, the Hartree-Fock-Roothaan method (HF) employing 6-31G (d,p) basis set was demonstrated to be an adequate method to describe clavulanic acid geometry. ${ }^{17}$ Although the structures were also fully optimized using Density Functional Theory (DFT) with B3LYP functional and employing 6-31G (d,p) basis set in order to take account the electron correlation factor in the properties studied. All calculations were performed using the Gaussian G03 program. ${ }^{18}$

In this methodology, the frequency calculations of the HF/6-31G (d,p) and DFT B3LYP/6-31G (d,p) optimized structures are made with the reagents and products and the results of $\varepsilon_{0}+H_{\text {corr }}$ and $\varepsilon_{0}+G_{\text {corr }}$ are used to obtain the thermodynamic parameters, according to the following equations:

$$
\begin{aligned}
\Delta H^{\circ}(298 K) & =\sum_{\text {products }} \Delta f H^{\circ}(298 K)-\sum_{\text {reagents }} \Delta f H^{\circ}(298 K) \\
\Delta G^{\circ}(298 K) & =\sum_{\text {products }} \Delta G^{\circ}(298 K)-\sum_{\text {reagents }} \Delta G^{\circ}(298 K)
\end{aligned}
$$

The electronic properties selected to evaluate were:

- The energies of the frontier orbitals HOMO ( $\left.\varepsilon_{\text {номо }}\right)$ and 
LUMO $\left(\varepsilon_{\text {LUMo }}\right)$ : these descriptors are related to the electron acid or base character of a given compound. ${ }^{19}$

- Absolute hardness $(\boldsymbol{\eta})$ : this property is resistance of the chemical potential to change in the number of electrons.

- Electronic chemical potential $(\boldsymbol{\mu})$ : it measures the escaping tendency (or fugacity) of electrons from the atomic or molecular system.

- Absolute electronegativity $(\chi)$ : it is a chemical property that describes the tendency of an atom or a functional group to attract electrons (or electron density) towards itself.

- Electrophilicity index $(\omega)$ : this property is a descriptor of reactivity that allows a quantitative of the electrophilic nature of a molecule.

The calculation of the last four properties employs five different equations ${ }^{20,21}$ that have $\varepsilon_{\text {номо }}$ and $\varepsilon_{\text {LUMO }}$ as variables, e.g., $\boldsymbol{\mu}=\left(\boldsymbol{\varepsilon}_{\text {LUMO }}-\boldsymbol{\varepsilon}_{\text {номо }}\right) / 2$.

To account for the solvent effect of ethyl acetate (the solvent used experimentally), single point energy calculation were performed using the Polarized Continuum Model (PCM) 22 at both HF 6-31G (d,p) and DFT B3LYP 6-31G (d,p) levels. For these calculations, the GAMESS free program was used ${ }^{23}$ and the same electronic properties described before were evaluated.

\section{RESULTS AND DISCUSSION}

\section{Study of the theoretical thermodynamic properties}

The reactions shown in Figure 1 were considered for this study. In the direct reaction CA (1) reacts with potassium 2-ethylhexanoate (2) to produce potassium clavulanate (3) and 2-ethylhexanoic acid (4), this is a typical acid-base reaction, where CA is an acid and 2-ethylhexanoate is a base. In the indirect reaction, CA (1) reacts with t-octylamine (5) to produce a stable intermediate (5'), which reacts with potassium 2-ethylhexanoate (2) to produce potassium clavulanate (3), t-octylamine (5) and 2-ethylhexanoic acid (4), this is a typical acid-base reaction as well, where acids and bases are indicated in Figure 1. The results obtained from the frequency calculation for the reagents and the products of both reactions are shown in Table 1.

Following Ochterski's methodology ${ }^{16}$ and applying the values obtained from the frequency calculations in equations 1 and 2 , the $\Delta \mathrm{H}^{\circ}$ and the $\Delta \mathrm{G}^{\circ}$ in Table 2 were calculated.

The $\Delta \mathrm{G}^{\circ}$ value indicates if a certain reaction is thermodynamically spontaneous or not, if the reaction present a high $\Delta \mathrm{G}^{\circ}$ value and negative, this indicates that the reaction is product favored, and the

\section{Direct Reaction:}

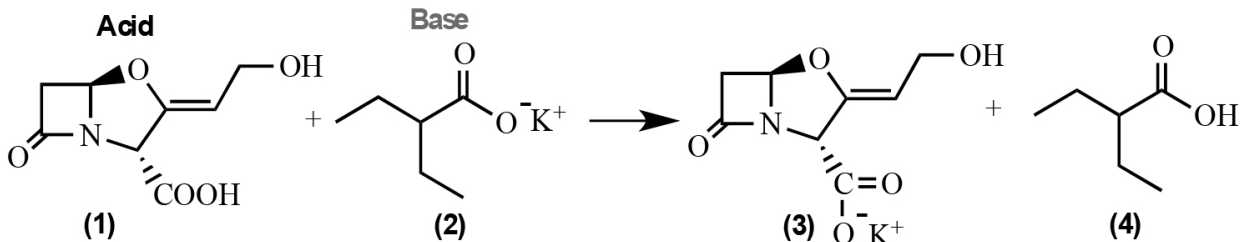

\section{Indirect Reaction:}<smiles>O=C(O)[C@H]1/C(=C/CO)O[C@@H]2CC(=O)N21</smiles>

(1)<smiles>CCCC(C)(C)CC(C)(C)N</smiles>

(5)

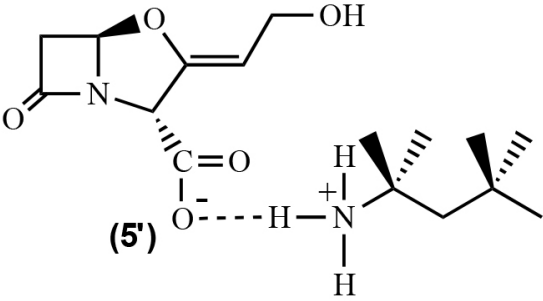<smiles>CC(C)C[C@@H](C)[IH]N[C@@H](C)CC(C)(C)C</smiles>

(5')<smiles>CCC(CC)C(=O)O[Na]</smiles>

(2)<smiles>[Z]C[C@H]1C[C@@H]2O/C(=C\CO)[C@@H](C(=O)O[Z10])N1C2=O</smiles>

(3)<smiles>CCC(C[18F])C(=O)OCCCCN(C)C(C)(C)CC(C)(C)C</smiles>

(4)

Figure 1. Representation of the mechanisms involved in the direct and indirect precipitation reactions of CA 
Table 1. Data obtained from the frequency calculation for both the direct and indirect reactions as shown in Figure 1 for Hartree-Fock 6-31G (d,p) and Density Functional Theory B3LYP 6-31G (d,p) optimized structures

\begin{tabular}{|c|c|c|c|c|}
\hline & \multicolumn{2}{|c|}{ Methodology (HF/6-31G (d,p)) } & \multicolumn{2}{|c|}{ Methodology (DFT/6-31G (d,p)) } \\
\hline & $\varepsilon_{0}+H_{\text {corr }}{ }^{*}$ & $\varepsilon_{0}+G_{\text {corr }} \#$ & $\varepsilon_{0}+H_{\text {corr }}^{*}$ & $\varepsilon_{0}+G_{\text {corr }} \#$ \\
\hline (1) & -736.16 & -736.21 & -740.36 & -740.41 \\
\hline (2) & -461.21 & -461.26 & -464.18 & -464.22 \\
\hline (3) & -736.19 & -736.24 & -740.38 & -740.42 \\
\hline (4) & -461.78 & -461.84 & -464.74 & -464.79 \\
\hline (5) & -368.19 & -368.23 & -370.80 & -370.85 \\
\hline$\left(5^{\prime}\right)$ & -1104.92 & -1105.00 & -1111.73 & -1111.80 \\
\hline (6) & -212.18 & -212.21 & -213.67 & -213.70 \\
\hline$\left(6^{\prime}\right)$ & -948.91 & -948.98 & -954.60 & -954.66 \\
\hline (7) & -423.19 & -423.24 & -426.13 & -426.18 \\
\hline$\left(7^{\prime}\right)$ & -1159.93 & -1160.02 & -1167.06 & -1167.12 \\
\hline (8) & -306.16 & -306.21 & -308.26 & -308.30 \\
\hline$\left(\mathbf{8}^{\prime}\right)$ & -1042.89 & -1042.97 & -1049.18 & -1049.24 \\
\hline (9) & -306.16 & -306.21 & -308.26 & -308.40 \\
\hline$\left(9^{\prime}\right)$ & -1042.89 & -1042.97 & -1049.19 & -1049.25 \\
\hline (10) & -345.17 & -345.22 & -347.54 & -347.59 \\
\hline$\left(10^{\prime}\right)$ & -1081.9 & -1081.99 & -1088.48 & -1088.54 \\
\hline (11) & -267.17 & -267.21 & -268.98 & -269.02 \\
\hline$\left(11^{\prime}\right)$ & -1003.89 & -1003.97 & -1009.90 & -1009.97 \\
\hline (12) & -345.15 & -345.20 & -347.53 & -347.58 \\
\hline$\left(12^{\prime}\right)$ & -1081.84 & -1081.91 & -1088.44 & -1088.51 \\
\hline (13) & -384.16 & -384.21 & -386.82 & -386.87 \\
\hline$\left(\mathbf{1 3}^{\prime}\right)$ & -1120.89 & -1120.98 & -1127.75 & -1127.81 \\
\hline (14) & -423.16 & -423.22 & -426.11 & -426.16 \\
\hline$\left(14^{\prime}\right)$ & -1159.91 & -1160.00 & -1167.04 & -1167.11 \\
\hline (15) & -501.18 & -501.24 & -504.68 & -504.74 \\
\hline$\left(15^{\prime}\right)$ & -1237.91 & -1238.00 & -1245.61 & -1245.68 \\
\hline
\end{tabular}

$* \Delta_{f} \mathrm{H}^{\circ}=\varepsilon_{0}+H_{\text {corr }}$ is the sum of electronic and thermal enthalpies. $\# \Delta \mathrm{G}^{\circ}=\varepsilon_{0}+G_{\text {corr }}$ is the sum of electronic and thermal free energies. The numbers in brackets and ' are the intermediates formed by CA and the precipitation agents numbered. All values are in $\mathrm{kcal} \mathrm{mol}^{-1}$.

Table 2. Thermodynamic parameters obtained for the precipitation reactions calculated with Hartree-Fock 6-31G (d,p) and Density Functional Theory B3LYP 6-31G (d,p)

\begin{tabular}{lccccc}
\hline & \multicolumn{4}{c}{$\begin{array}{c}\text { Methodology } \\
\text { HF/6-31G }(\mathrm{d}, \mathrm{p})\end{array}$} & \multicolumn{2}{c}{$\begin{array}{c}\text { Methodology } \\
\text { DFT/6-31G }(\mathrm{d}, \mathrm{p})\end{array}$} \\
\hline & $\begin{array}{c}\text { Precipita- } \\
\text { tion agent }\end{array}$ & $\Delta \mathrm{H}^{\circ}$ & $\Delta \mathrm{G}^{\circ}$ & $\Delta \mathrm{H}^{\circ}$ & $\Delta \mathrm{G}^{\circ}$ \\
\hline $\begin{array}{l}\text { Direct } \\
\text { reaction }\end{array}$ & $\mathbf{( 2 )}$ & -374.22 & -377.58 & -363.96 & -363.96 \\
\hline & $\mathbf{( 5 )}$ & -374.22 & -377.58 & -363.96 & -363.96 \\
& $\mathbf{( 6 )}$ & -374.22 & -377.58 & -363.96 & -363.96 \\
& $\mathbf{( 7 )}$ & -374.22 & -377.58 & -363.96 & -363.96 \\
& $\mathbf{( 8 )}$ & -374.22 & -377.58 & -363.96 & -363.96 \\
Indirect & $\mathbf{( 9 )}$ & -374.22 & -377.58 & -363.96 & -363.96 \\
reaction & $\mathbf{( 1 0 )}$ & -374.22 & -377.58 & -363.96 & -363.96 \\
& $\mathbf{( 1 1 )}$ & -374.22 & -377.58 & -363.96 & -363.96 \\
& $(\mathbf{1 2})$ & -374.22 & -377.58 & -363.96 & -363.96 \\
& $(\mathbf{1 3})$ & -374.22 & -377.58 & -363.96 & -363.96 \\
& $\mathbf{( 1 4 )}$ & -374.22 & -377.58 & -363.96 & -363.96 \\
& $\mathbf{( 1 5 )}$ & -374.22 & -377.58 & -363.96 & -363.96 \\
\hline
\end{tabular}

All values are in $\mathrm{kcal} \mathrm{mol}^{-1}$. equilibrium constant of the product formation is high, therefore $\Delta \mathrm{G}^{\circ}$ and $\mathrm{K}$ are related for the equation (3).

$$
\Delta G^{\circ}=-R T \ln K
$$

By the analysis of the $\Delta \mathrm{G}^{\mathrm{o}}$ values in Table 2, it is possible to observe that for the calculations using Hartree-Fock 6-31G (d,p) and DFT B3LYP/6-31G (d,p) optimized structures there is no difference in the values of the calculated thermodynamic properties for the direct and indirect reactions. It can also be observed and there is no significant difference between the two methodologies employed. It was thought that the electron correlation factor, which is included in the DFT method, would give an important difference in the thermodynamic properties, but this was not observed. It may be involved with the formalism of Ochterski's methodology, ${ }^{16}$ which may not be appropriate to the systems studied here.

Taking into account the other precipitation agents (Figure 2), compounds (6')-(15'), the $\Delta \mathrm{G}^{\circ}$ values calculated using Hartree-Fock 6-31G (d,p) and DFT B3LYP/6-31G (d,p) methodologies, presented in Table 2, for the indirect reaction also do not present any differences.

\section{Quantum properties studied and solvent effect}

With the intention of verifying if the reactive indexes correlate with the theoretical thermodynamic results, the aforementioned reactivity parameters were calculated for Hartree-Fock 6-31G (d,p) and Density Functional Theory B3LYP 6-31G (d,p) optimized structures. The energies of the frontier orbitals, $\varepsilon_{\text {Lumo }}$ and $\varepsilon_{\text {номо }}$, and the reactivity indexes $\chi, \eta, \mu$ and $\omega$ calculated with and without solvent effect are given in Table 3.

Analyzing only the left side of both direct reaction and indirect reaction (Figure 1), in the first reaction $\mathrm{CA}$ is acid and potassium 2-ethylhexanoate is a base. In the indirect reaction, the intermediate formed by CA and t-octylamine is an acid and 2-ethylhexanoate is a base. The difference between direct and indirect reactions is the acid. When different acid base reactions with the same base are compared, the reaction more product favored is the one that presents the strongest acid, and a compound with strong acidic character tends to have higher $\chi, \eta, \mu$ and $\omega$ values, and lower $\varepsilon_{\text {номо }}$ and $\mu$ values.

Considering all these aspects and analyzing the data shown in Table 3, it is observed that the acids formed by CA and the precipitation agents, compound (5')-(15'), have higher $\chi, \eta$ and $\omega$ values and lower $\varepsilon_{\text {номо }}$ and $\mu$ values than CA, compound (1)* in all methodologies, Hartree-Fock 6-31G (d,p) and B3LYP 6-31G (d,p) including or not the solvent effect, used to calculate these reactivity indexes.

Considering Hartree-Fock 6-31G (d,p) methodology not including solvent effect for the compounds (6)-(15'), they have $\chi, \eta$, and $\omega$ values equal to $1.85 \mathrm{eV}, 6.43 \mathrm{eV}, 0.25 \mathrm{eV}$, respectively, or higher, and $\varepsilon_{\text {номо }}$ and $\mu$ values equal to $-8.52 \mathrm{eV}$ and $1.89 \mathrm{eV}$, respectively, or lower. Considering the same methodology for the compounds (1)*, it has $\chi, \eta, \omega, \varepsilon_{\text {номо }}$ and $\mu$ values equal to $-1.28 \mathrm{eV}, 6,56 \mathrm{eV}, 0.12 \mathrm{eV}$, $-5.26 \mathrm{eV}$ and $1.28 \mathrm{eV}$, respectively. Evaluating and comparing $\chi, \eta, \omega$, $\varepsilon_{\text {номо }}$ and $\mu$ values for the compound (5')-(15') and compound (1)*, considering the results of Hartree-Fock 6-31G (d,p) methodology, not including solvent effect and the others three methodologies in Table 3 , indicates that the compounds $\left(5^{\prime}\right)-\left(15^{\prime}\right)$ are stronger acids than CA. This factor contributes to the indirect reactions that use precipitation agents, to be product favored.

This study corroborates the studies of Hirata and coworkers, ${ }^{14,15}$ where the authors concluded that the indirect reaction is appropriate for application as the last step in the CA fermentation broth purification process. It is also suggested that this reaction promotes purification without causing $\mathrm{CA}$ degradation, increases reaction 


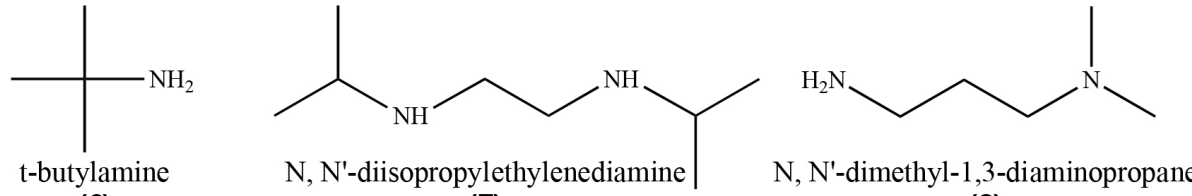

(6)

(7)<smiles>CCN(CC)CCN</smiles>

$\mathrm{N}, \mathrm{N}$-dimethyl-1,2-diaminopropane

(9)

(10)
(8)

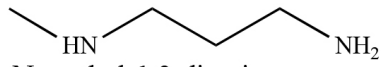

N-methyl-1,3-diaminopropane

(11)<smiles>CN(C)CCN(C)C</smiles>

$\mathrm{N}, \mathrm{N}, \mathrm{N}$ ', N'-tetramethyl-1,2-diaminoethane

(12)<smiles>CN(C)CCCCN(C)C</smiles>

$\mathrm{N}, \mathrm{N}, \mathrm{N}^{\prime}, \mathrm{N}^{\prime}$-tetramethyl-1,4-diaminobutane

(14)<smiles>CN(C)CCCN(C)C</smiles>

$\mathrm{N}, \mathrm{N}, \mathrm{N}^{\prime}, \mathrm{N}^{\prime}$-tetramethyl-1,2-diaminopropane

(13)

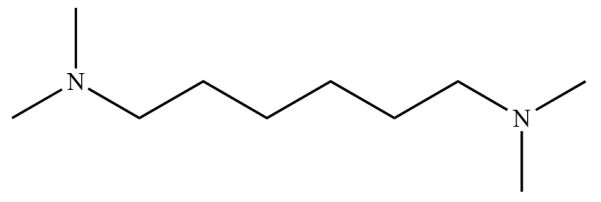

$\mathrm{N}, \mathrm{N}, \mathrm{N}^{\prime}, \mathrm{N}^{\prime}$-tetramethyl-1,6-diaminobutane

(15)

Figure 2. Precipitation agents used to obtain a stable amine intermediate of CA

Table 3. Frontier Molecular Orbital energies, reactivity indicators and solvent effect from ethyl acetate for compounds under study calculated at HF/6-31G $(\mathrm{d}, \mathrm{p})$ and DFT B3LYP/ 6-31G (d,p) levels

\begin{tabular}{|c|c|c|c|c|c|c|c|c|c|c|c|c|}
\hline \multirow[b]{2}{*}{ Compounds } & \multicolumn{6}{|c|}{ Methodology (HF/6-31G (d,p)) } & \multicolumn{6}{|c|}{ Methodology (DFT/6-31G (d,p)) } \\
\hline & $\varepsilon_{\text {номо }}$ & $\varepsilon_{\text {LUMO }}$ & $\chi$ & $\eta$ & $\mu$ & $\omega$ & $\varepsilon_{\text {номо }}$ & $\varepsilon_{\text {LUMO }}$ & $\chi$ & $\eta$ & $\mu$ & $\omega$ \\
\hline$(1)^{*}$ & -5.28 & 7.84 & -1.28 & 6.56 & 1.28 & 0.12 & -1.36 & 3.26 & -0.95 & 2.31 & 0.95 & 0.19 \\
\hline (2) & -4.73 & 8.95 & -2.11 & 6.84 & 2.11 & 0.32 & -0.46 & 5.25 & -2.39 & 2.85 & 2.39 & 1.00 \\
\hline$\left(5^{\prime}\right)$ & -8.65 & 4.35 & 2.15 & 6.50 & -2.15 & 0.35 & -6.01 & -0.22 & 3.11 & 2.89 & -3.11 & 1.68 \\
\hline$\left(6^{\prime}\right)$ & -9.09 & 4.54 & 2.27 & 6.81 & -2.27 & 0.38 & -5.93 & -0.49 & 3.21 & 2.72 & -3.21 & 1.89 \\
\hline$\left(7^{\prime}\right)$ & -8.76 & 5.06 & 1.85 & 6.91 & -1.85 & 0.25 & -5.58 & 0.60 & 2.49 & 3.09 & -2.49 & 1.00 \\
\hline$\left(8^{\prime}\right)$ & -9.14 & 4.63 & 2.25 & 6.88 & -2.25 & 0.37 & -5.77 & 0.43 & 2.67 & 3.10 & -2.67 & 1.15 \\
\hline$\left(9^{\prime}\right)$ & -8.70 & 4.49 & 2.10 & 6.59 & -2.10 & 0.34 & -5.52 & 0.54 & 2.49 & 3.03 & -2.49 & 1.02 \\
\hline$\left(10^{\prime}\right)$ & -8.76 & 4.68 & 2.04 & 6.72 & -2.04 & 0.31 & -5.58 & 0.49 & 2.54 & 3.03 & -2.54 & 1.07 \\
\hline$\left(11^{\prime}\right)$ & -9.14 & 4.68 & 2.23 & 6.91 & -2.23 & 0.36 & -5.99 & 0.46 & 2.76 & 3.22 & -2.76 & 1.18 \\
\hline$\left(12^{\prime}\right)$ & -8.52 & 4.35 & 2.08 & 6.43 & -2.08 & 0.34 & -5.36 & -0.05 & 2.71 & 2.65 & -2.71 & 1.38 \\
\hline$\left(13^{\prime}\right)$ & -8.76 & 4.98 & 1.89 & 6.87 & -1.89 & 0.26 & -5.60 & 0.54 & 2.53 & 3.07 & -2.53 & 1.04 \\
\hline$\left(14^{\prime}\right)$ & -9.39 & 4.19 & 2.60 & 6.79 & -2.60 & 0.50 & -5.74 & -0.05 & 2.90 & 2.84 & -2.90 & 1.48 \\
\hline \multirow[t]{2}{*}{$\underline{\left(15^{\prime}\right)}$} & -8.76 & 4.98 & 1.89 & 6.87 & -1.89 & 0.26 & -5.60 & 0.57 & 2.51 & 3.08 & -2.51 & 1.02 \\
\hline & \multicolumn{12}{|c|}{ Solvent effect from ethyl acetate } \\
\hline$(1)^{*}$ & -8.42 & 5.26 & 1.58 & 6.84 & -1.58 & 0.18 & -4.76 & 0.68 & 2.04 & 2.72 & -2.04 & 0.76 \\
\hline (2) & -8.77 & 6.91 & 0.93 & 7.84 & -0.93 & 0.05 & -4.43 & 3.19 & 0.62 & 3.81 & -0.62 & 0.05 \\
\hline$\left(5^{\prime}\right)$ & -9.16 & 4.62 & 2.27 & 6.89 & -2.27 & 0.37 & -6.17 & -0.26 & 3.21 & 2.95 & -3.21 & 1.75 \\
\hline$\left(6^{\prime}\right)$ & -9.39 & 4.52 & 2.43 & 6.95 & -2.43 & 0.43 & -5.84 & 0.60 & 2.62 & 3.22 & -2.62 & 1.07 \\
\hline$\left(7^{\prime}\right)$ & -8.76 & 5.07 & 1.84 & 6.91 & -1.84 & 0.25 & -5.49 & 0.71 & 2.39 & 3.10 & -2.39 & 0.92 \\
\hline$\left(8^{\prime}\right)$ & -9.16 & 4.65 & 2.25 & 6.90 & -2.25 & 0.37 & -5.68 & 0.55 & 2.56 & 3.11 & -2.56 & 1.06 \\
\hline$\left(9^{\prime}\right)$ & -8.73 & 4.50 & 2.11 & 6.61 & -2.11 & 0.34 & -5.44 & 0.66 & 2.39 & 3.05 & -2.39 & 0.94 \\
\hline$\left(10^{\prime}\right)$ & -8.78 & 4.70 & 2.04 & 6.74 & -2.04 & 0.31 & -5.49 & 0.61 & 2.44 & 3.05 & -2.44 & 0.98 \\
\hline$\left(11^{\prime}\right)$ & -9.15 & 4.72 & 2.21 & 6.93 & -2.21 & 0.35 & -5.89 & 0.56 & 2.66 & 3.22 & -2.66 & 1.10 \\
\hline$\left(12^{\prime}\right)$ & -8.98 & 3.94 & 2.52 & 6.46 & -2.52 & 0.49 & -5.29 & 0.04 & 2.62 & 2.66 & -2.62 & 1.29 \\
\hline$\left(\mathbf{1 3}^{\prime}\right)$ & -8.79 & 5.00 & 1.89 & 6.89 & -1.89 & 0.26 & -5.53 & 0.66 & 2.43 & 3.09 & -2.43 & 0.96 \\
\hline$\left(14^{\prime}\right)$ & -9.39 & 4.20 & 2.59 & 6.79 & -2.59 & 0.49 & -5.68 & 0.03 & 2.82 & 2.85 & -2.82 & 1.40 \\
\hline$\left(\mathbf{1 5}^{\prime}\right)$ & -8.78 & 5.00 & 1.89 & 6.89 & -1.89 & 0.26 & -5.52 & 0.67 & 2.42 & 3.09 & -2.42 & 0.95 \\
\hline
\end{tabular}

(1)*represent the deprotonated form of 1, its conjugated base; The numbers in brackets and ' are the intermediate formed by CA and the agents numbered. All values are in $\mathrm{kcal} / \mathrm{mol}$. All values are in $\mathrm{eV}$. 
stability without forming oils, colloids or incrustations, and allows for a broader operational range, thus favoring an industrial scale application.

\section{CONCLUSIONS}

Finally, it is possible to say that the quantum reactive indexes show direct correlation with the higher spontaneity of the indirect reaction for $\mathrm{HF}$ and DFT methods. From the quantum reactive indexes values $\left(\chi, \eta, \omega, \varepsilon_{\text {номо }}\right.$ and $\left.\mu\right)$, it is possible to say that one characteristic is necessary to have a higher percentage yield: more acid character of the compounds formed by $\mathrm{CA}$ and the precipitation agents (when compared to CA). As very consistent results have been obtained in this work for the main and also for other precipitation agents, in the future these theoretical properties could be useful to evaluate new precipitation agents. This would economize time and, most important, reagents and equipment, improving the industrial process.

\section{ACKNOLEDGEMENTS}

The authors would like to thanks FAPESP for the grants (05/55079-4, 06/59474-8 and 04/15540-1), CAPES, FAPEMIG (APQ-01285-14 and APQ-01572-14) and CNPq. This work is a collaboration research project of members of the Rede Mineira de Química (RQ-MG) supported by FAPEMIG (Project: CEX-RED-00010-14).

\section{REFERENCES}

1. Buynak J. D.; Biochem. Pharmacol. 2006, 71, 930.

2. Rolinson G. N.; Rev. Infect. Dis. 1991, 13, 5727.

3. Brown A. G.; Butterworth D.; Cole M.; Hanscomb G.; Hood J. D.; Reading C.; Rolinson G. N.; J. Antibiot. 1976, 6, 668.

4. Liras P.; Rodríguez-Garcia, A.; Appl. Microbiol. Biotechnol. 2000, 54, 467.

5. Haginaka J.; Nakagawa T.; Uno T.; Chem. Pharm. Bull. 1981, 29, 3334.

6. Bersanetti P. A.; Almeida R. M. R. G.; Barboza M.; Araujo M. L. G. C.; Hokka C. O. Biochem. Eng. J. 2005, 23, 31.

7. Cook M. A.; Curzons A. D.; Wilkins R. B.; US Pat. 4,647,659 1987.

8. Weber P. G.; US Pat. 5,741,903 1998.

9. Yang H. S.; Choi N. H.; Lee S. C.; Ham Y. B.; Min K. B.; EP 0594099A1 1994
10. Cook M. A.; Wilkins R. B.; WO Pat. 255571993.

11. Buterfly P. G.; Keohane G. J.; Kosal E. F.; WO Pat. 473011997 (CA 2257968 Al).

12. Capuder E.; US Pat. 6,274,575 B1 2001.

13. Butterfly P. G.; Keohane G. J.; Kosal E. F.; US Pat. 6,414,142 2002.

14. Hirata, D.; Oliveira, J. ; Leao, K. ; Rodrigues, M. ; Ferreira, A. ; Giulietti, M. ; Barboza, M. ; Hokka, C. O. Sep. Purif.Technol. 2009, 66, 598.

15. Hirata, D. B.; Oliveira, J. H. H. L.; Giulietti, M.; Rodrigues, M. I.; Barboza, M.; Hokka, C. O.; Braz. J. Chem. Eng. 2013, 30, 231.

16. Ochterski J. W.; Gaussian Technical Support Information, Gaussian Inc, Pittsburgh, PA 2000.

17. Granato A. C.; Costa E. B.; Barboza M.; Trsic M.; In Microorganisms in industry and Environment; Mendez-Vilas, A., ed.; World Scientific Publishing Co., 2010, pp. 713-718.

18. Frisch, M. J.; Trucks, G. W.; Schlegel, H. B.; Scuseria, G. E.; Robb, M. A.; Cheeseman, J. R.; Montgomery, Jr., J. A.; Vreven, T.; Kudin, K. N.; Burant, J. C.; Millam, J. M.; Iyengar, S. S.; Tomasi, J.; Barone, V.; Mennucci, B.; Cossi, M.; Scalmani, G.; Rega, N.; Petersson, G. A.; Nakatsuji, H.; Hada, M.; Ehara, M.; Toyota, K.; Fukuda, R.; Hasegawa, J.; Ishida, M.; Nakajima, T.; Honda, Y.; Kitao, O.; Nakai, H.; Klene, M.; Li, X.; Knox, J. E.; Hratchian, H. P.; Cross, J. B.; Bakken, V.; Adamo, C.; Jaramillo, J.; Gomperts, R.; Stratmann, R. E.; Yazyev, O.; Austin, A. J.; Cammi, R.; Pomelli, C.; Ochterski, J. W.; Ayala, P. Y.; Morokuma, K.; Voth, G. A.; Salvador, P.; Dannenberg, J. J.; Zakrzewski, V. G.; Dapprich, S.; Daniels, A. D.; Strain, M. C.; Farkas, O.; Malick, D. K.; Rabuck, A. D.; Raghavachari, K.; Foresman, J. B.; Ortiz, J. V.; Cui, Q.; Baboul, A. G.; Clifford, S.; Cioslowski, J.; Stefanov, B. B.; Liu, G.; Liashenko, A.; Piskorz, P.; Komaromi, I.; Martin, R. L.; Fox, D. J.; Keith, T.; Al-Laham, M. A.; Peng, C. Y.; Nanayakkara, A.; Challacombe, M.; Gill, P. M. W.; Johnson, B.; Chen, W.; Wong, M. W.; Gonzalez, C.; Pople, J. A.; Gaussian 03, Gaussian, Inc., Wallingford CT, 2004.

19. Nguyên T. A.; Frontier Orbitals: A Practical Manual, Chichester, 2007.

20. Pearson R. G.; Proc. Natl. Acad. Sci. U. S. A. 1986, 83, 8440.

21. Parr R. G.; Szentpály L. V.; Liu S.; J. Am. Chem. Soc. 1999, 121, 1922.

22. Cramer C. J.; Truhlar D. G.; Chem. Rev. 1999, 99, 2161.

23. Schmidt, M. W.; Baldridge, K. K.; Boatz, J. A.; Elbert, S. T.; Gordon, M. S.; Jensen, J. J.; Koseki, S.; Matsunaga, N.; Nguyen, K. A.; Su, S.; Windus, T. L.; Dupuis, M.; Montgomery, J. A.; J. Comput. Chem. 1993, 14,1347 . 